\title{
Food Security and outlook on Life of Undergraduates and Postgraduates in University of Uyo
}

\author{
Opara, D. C., Ph.D1, Madukosiri, C. H., Ph.D2 \\ 1Department of Community Health, University of Uyo, Uyo, Akwa Ibom State 2Biochemistry Department, \\ Niger Delta University, Wilberforce Island, Nigeria *
}

\begin{abstract}
Food insecurity continues to be a huge problem in Nigeria, despite the various strategies put in place by the government to combat the situation. The cost of living remains high while the standard of living is perpetually low in numerous states of the country. The food insecurity in the country has been attributed to negative macroeconomic indices, decades of neglect of the agricultural sector, massive rural to urban migration by able bodied youths, poor road and transportation networks among various others. The situation is now exacerbated by dwindling oil revenues, which remains the main stay of Nigeria's economy. The study aimed at documenting the food security, cost of living, compensatory feeding pattern/coping strategy, quality of life as well as socio-demographic variables of undergraduates and postgraduates in a University of Uyo in Akwa Ibom State. Random sampling was used to select 8 Departments from the various Faculties in the university. Forty students were selected from each of the departments through simple random sampling. A total of 320 respondents participated in the study. Most of the respondents were male (60.3\%), between the ages of 21-34 years (60.3\%), in their third/fourth year in school (35.5\%) and in faculty of basic medicals (16.1\%). Male respondents (2.9\%) and postgraduates were also more food secure (2.6\%) than females and undergraduates, respondents whose mother are senior civil servants and have attained tertiary institution are more food secure (2.3\% and $3.5 \%$ respectively) than respondents whose mother has a lower qualification. Most of the respondents feel frustrated because of insufficient funds, academic stress and hence are not satisfied with their quality of life even though academic achievement is accepted to be the most important determinant of accomplishing future prospects. It is hence recommended that student live with their parents/guardian and universities should ensure that their expectations of the students are within par.
\end{abstract}

Keywords- Coping strategy, Food security, University, Quality

\section{INTRODUCTION}

According to the experts group of American Institute of Nutrition, food security is defined as "Access by all people at all times to safe and nutritious food for an active, healthy life [1], [2]. Other factors like sanitary conditions, water quality, infectious diseases and access to primary health care and food choices play a role in general well being. Notably household food insecurity can be transitory or permanent [3].

Household food insecurity has been linked with lower nutrient intake, lower self-reported general physical and mental health status in adults [4],[5]; causes of which is income related and the its proportion controlled by a woman [6], [7]-[8] with psychological and physical consequences [8]. Effects of household food insecurity on children has been extensively researched [9], [10] evident in emotional disability and physical appearance [9],[10]-[11] Families with older children are reported to be more food insecure; compensatory feeding patterns engaged by low income families includes usage of nutrient supplement, high-energy boosters [12] and this is affect

Globally there have been several moves by organizations to eradicate hunger and malnourishment. The first Millennium Development Goal (MDG) included in its targets the reduction by half of the amount of people who suffer from acute starvation and who earn less than $\$ 1$ per day by the year 2015 [13]. Sadly, number of people suffering from hunger has been on the increase since 1996 [14].

Food insecurity remains a major challenge in Nigeria, causes of which include [15]: high prices of staple food items, drought, political situation in neighboring countries like Chad, Cameroun and Niger and climatic changes [16]. Other causes are increase in the age of household head and size [17]. Policies and initiatives geared toward increase in availability of food in the country include: Special Programme for Food Security (SPFS), Root and Tuber Expansion Programme, Agricultural Development Project, Operation Feed the Nation, Green Revolution, Fadama Development Project, Community-based agricultural, rural development Schemes [16],[18] and PROSAB which led to an increase in food security in Borno State [19]. Household food security has been extensively researched in various states in Nigeria and high level of food insecurity was posited respective states [15],[20],[21],[22],[23],[24]-[26]. Household consequences of food insecurity can be physical, psychological sociofamilial and poorer self-reported health status of adults [27], [28]-[29].Adding to the risk of food insecurity in Nigeria is the issue of nonpayment and reduction in salary paid. Judicial workers in 
Imo State reportedly shut down judicial courts in the state over what they termed "non-payment of arrears of salaries and allowances owed us by the state government". Similarly, Imo State University, (IMSU), Owerri was locked for two months due to non-payment of their emoluments by government. Some of the aggrieved workers, who spoke to [30] said they are strongly opposed to the 30 percent cut on their January 2016 salary [30]. A similar situation was reported in Oyo, Nasarawa, Kogi, Kwara, and Ekiti States [31], [32]. Following the foregoing, it becomes imperative that food security, cost of living, compensatory feeding pattern/coping strategy and outlook on life of university students who are the future brains of the country be investigated. This research documented findings to these issues and also socio demographic characteristics of respondents in University of Uyo in June, 2016.

\section{METHODS}

Area of the Study: The study was carried out in University of Uyo, Akwa Ibom state. Uyo is the capital of Akwa Ibom state in the South-South region of Nigeria. Uyo is situated at 5.03。 North latitude, 7.93。 East longitude and 196 meters elevation above the sea level; with a population of 124690.

Sampling: Purposive sampling was employed in the selection of the following departments/faculties: Law, Art, Education, Science, Engineering, Basic medicals, Pharmacy, Postgraduate. Selected respondents were students admitted in the aforementioned Departments/Faculties in University of Uyo. The sample size of 192 was derived using the formula:

$\mathrm{n}=\mathrm{zpq} / \mathrm{d} 2$

Where $\mathrm{z}=95 \%$; confidence interval $=1.96$

$\mathrm{p}=$ probability of event occurring, (taken as $43.6 \%$, as reported household food insecurity without hunger by [15]); $\mathrm{p}=0.436$

$\mathrm{q}=1-\mathrm{p}=1-0.436=0.564$

$\mathrm{d}=0.05$ which is acceptable margin of error.

Therefore $\mathrm{n}=192$

This was increased to 320 to take care of attrition and invalid data.

Instrumentation: Structured questionnaire was administered to 320 respondents. Section A: Socio Demographic Characteristics: Data collected include socio-economic characteristics of the respondents such as gender, age, maternal education, occupational of parents, household size and department/faculty. Section B: Food Security of Respondents: This study used the USDA approach for the analysis of household food security in the selected study area. The USDA approach groups households with the aid of a constructed food security scale that ranges between 0 and 10 (a number continuum). Household scale in this approach is basically dependent on the household responses to the structured survey questions. Each of these questions had three responses; namely, often true, sometimes true and never true. Both often true and sometimes true was considered as affirmative response because it shows that the condition took place at some time during the year of the study. The household food security status was categorized into four groups; namely, food secure households, food insecure without hunger households, food insecure with moderate hunger households and food insecure with severe hunger households. Section C: Cost of Living of Respondents: The respondents were asked how much they spend on feeding, transport and assignment/other academic activities. Section D: Compensatory Feeding Pattern/Coping Strategy of Respondent: The respondents were asked if they engage in any economic activity to raise funds, what the activity is and what they do when the food/money available is not enough. Section E: Outlook on Life of Respondents: The Outlook on life of respondents was also measured via questions such as: are you satisfied with your quality of life? Do you feel frustrated that you do not have enough funds to meet your basic needs?

Statistical Analysis: The data collected was analyzed using Statistical Package for Social Sciences (SPSS), version 20.0 (SPSS Inc. Chicago, IL, USA). The statistical significant level was set at $\mathrm{p}<0.05$. The categorical variable results is presented as frequency and its percentage. Inferential statistics was made using chi square.Ethics Approval: Ethical approval for the study was obtained from the Ethical Committee of Faculty of Basic Medical Sciences, College of Health Sciences, University of Uyo. In addition the purpose of the study was explained to prospective respondents, the confidentiality of the information they were to provide assured and they were not required to supply their names. They were free to opt out. Only those that gave their individual consent were recruited as respondents.

\section{A. Socio-demographic Characteristics}

\section{RESULTS}

Most of the respondents were male $(187,60.3 \%)$ while female respondents were $123(39.7 \%)$. Majority of the respondents were between 21-34 years $(60(19.4 \%)$ female and $127(41 \%)$ male) in third/fourth year in school (41 (31.2\%) female and 63(20.3\%) male) and in faculty of basic medical sciences (23(7.4\%) female and 
$27(8.7 \%)$ male). Table 1 and 2 shows relevant socio-demographic characteristics of respondent. There was no significant difference their socio-demographic characteristics.

\section{B. Food security of respondents}

Analysis of respondents according to their residence showed that only $16(5.2 \%)$ were food secure, $37(11.9 \%)$ were food insecure without hunger, 70(22.6\%) were food insecure with moderate hunger and $187(60.3 \%)$ were food insecure with severe hunger. Further analysis showed that respondents that live off campus without parents/guardian were the most food insecure with severe hunger $(82,26.5 \%)$; this was followed by respondents that live on campus $(60,19.4 \%)$ and the least was respondents that live off campus with their parents/guardian $(45,14.5 \%)$. However no significant difference was recorded in this category (Table 3 ). There is no significant difference in food security of respondents that engage in economic activities to raise more funds and those who do not (table 3). Mother's occupation of respondents was also analyzed and result showed no significant difference in this category, however respondents whose mother are senior civil servant were more food secure $(7,2.3 \%)$; followed by businesswomen $(4,1.3 \%)$ while junior civil servants, unemployed and farmer/trader was $1(0.3 \%)$ each (table 3 ). Respondents that received above N30,000 monthly allowance were more food insecure $(8,2.6 \%)$ than those that received less while respondents that received between N5,000 and $\mathrm{N} 10,000$ formed the highest number of food insecure with severe hunger $(65,21 \%)$; showing no significant difference (table 3). Post graduate respondents were more food secure $(8,2.6 \%)$, followed by respondents in their third/fourth year $(6,1.9 \%)$ in school. However no significant difference was recorded. This is shown in table 3. Male respondents were more food secure $(9,2.9 \%)$ than females $(7,2.3 \%)$ though not significantly. Also recorded was that respondents in faculty of basic medicals were more food secure $(6,1.9 \%)$ while faculty of engineering shown the highest number of food insecure with severe hunger $(36,11.6 \%)$ followed by faculty of education $(35,11.3 \%)$, though not significantly (table 3 ). Further analysis of food security revealed that respondents whose mother attained tertiary education were more food secure $(11,3.5 \%)$ than respondents whose mother's highest education attained was secondary level $(5,1.6)$; whereas respondents whose mother's educational qualification was primary, vocational/trained were not food secure and this is same for mothers with no formal education; but not significantly (table 4). Father's occupation of respondents showed no significant difference, however senior civil servants and businessmen recorded the highest number of food secure respondents $(4,1.3 \%$ each) shown in table 4 . Household size of between 5 and 7 has the highest number of respondents that are food insecure with severe hunger $(96,31 \%)$ (table 4). No significant difference was recorded when food security of respondents were analyzed according to their ages; however respondents aged 21-34 years were the most food secure $(10,3.2 \%)$ followed respondents of $35-46$ years $(5,1.6 \%)$ (Table 4$)$

\section{Cost of Living of Respondents}

Feeding: Most of the respondents $(167,54 \%)$ spend above N5000 on feeding monthly and this comprises of 65 (21\%) females and $102(34 \%)$. Further analysis of monthly allowance showed that most of the respondents that received above N30000 $(31,10 \%)$ spend more than N5000 on feeding monthly and just $3(1.0 \%)$ of them spend below N5000 monthly on feeding. There was no significant difference in monthly feeding expense across gender and monthly allowance (table 5).

Transport: Most of the respondents (116, 37\%) spend below N5000 monthly on transport and this consist of 40 (13\%) females and 76 (24\%) males. Respondents which received monthly allowance of N5000 to N10000 formed the highest number of respondents $(52,16.8 \%)$ that spends below N5000 monthly on transport and this followed by respondents that received less than N5000 as monthly allowance (22, 7.1\%), though not significantly. This is shown in table 5.

Assignments and Other Academics Activities: Most of the respondents (141, 45.5\%) spend between N5000N10000 monthly on assignments and other academic activities. This is made up of 62 (20\%) females and 79 (25.5\%) male. $36(11.6 \%)$ of respondents that received monthly allowance of between N5000-N1000 formed the highest number of respondents that spend below N5000 and this is followed by respondents that receive below N5000 monthly allowance. This is shown in table 5.

\section{Coping strategy of respondents}

Compensatory Feeding Pattern: When there is insufficient food/money, most of the respondents (118, 38.1\%) borrow money from friends/neighbors/relatives (F/N/R) comprising of 37 (11.9\%) females and 81 (26.1\%). This is followed by respondents $(109,35.2 \%)$ that just pray for divine provision (female- 54 (17.4\%), male-55 $(17.7 \%)) .42(13.5 \%)$ starve (female-16 (5.2), male-26 (8.4)) while the least number of respondents (41 (13.2)) go ahead to collect food from F/N/R; this category of respondents comprise of $16(5.2 \%)$ female and $25(8.1 \%)$ males. Further analysis of their food security revealed that respondents that borrow money from F/N/R were more food secure $(6,1.9 \%)$ than the other categories. This is followed by respondents that collect food from 
F/N/R (5, 1.6\%) while the least food secure respondents are those that just starve $(1,0.3 \%)$. No significant difference was recorded in this analysis. Table 6 shows a detailed result of this analysis.

Economic Activities: In an effort to enhance food security, some respondents $(158,100 \%)$ engage in economic activities such as trading, farming or taking up any kind of work to raise more funds. This includes 53 (33.5\%) females and 105 (66.5\%) males (table 6). Data analysis showed that most of the respondents (92, 58.2\%) take up any kind of work which includes $20(12.7 \%)$ females and $72(45.6 \%)$ males and the least activity engaged in by respondents $(14,8.9 \%)$ is farming (female-6 (3.8\%), male-8 $(5.1 \%)$ though not significantly different (table 6). Further analysis however showed that respondents that trade are more food secure $(4,2.5 \%)$ than those that work $(3,1.9 \%)$ or farm $(1,0.3 \%)$ but not significantly. Table 6 shows the details.

\section{E. Outlook on life of respondents}

The quality of life of the respondents was also measured; analysis of which showed that most of the respondents $(133,42.9 \%)$ often times feel frustrated that they do not have enough money to meet their basic needs. This comprises of $50(16.1 \%)$ females and $83(26.8 \%)$ male. Next in this category are respondents $(122$, $39.4 \%$ ) that sometimes feel frustrated (female-50 (16.1\%), male- $72(23.2 \%)$ ). Only a few number of the respondents $(55,17.7 \%)$ do not feel frustrated that they do not have enough money to meet their basic needs (table 7). The most frustrating thing experienced by the respondents was economic related $(152,49 \%)$, followed by academics $(108,34.8 \%)$, social $(37,11.9 \%)$ (table 7$)$. Further analysis on quality of life showed that the area of life of the respondents that suffers due to insufficient monthly allowance is mainly the academic aspect (92, $29.8 \%$ ), followed by feeding $(71,23.0 \%)$. Also recorded is that most of the respondents $(195,62.9 \%)$ feel sure of their future prospects while just few $(32,10.3 \%)$ often times are unsure (table 7). 72(23.2\%) of the respondents however do not feel satisfied with their quality of life. Most of the respondents $(152,49.0 \%)$ however believe academic achievements to be the most important determinant of achieving their future prospects.

\section{DISCUSSION}

Recently more young people than ever are being admitted into the university. Admission has increased among groups historically underrepresented in higher education, including women, minorities, and those from low-income and poor families [33]. This is partly due to the numerous benefits accrued to those with postsecondary credentials such as higher wages [34]. Despite this increase in admission however, there still exist graduation gaps which is brought about majorly by difference in family income which goes a long way to determine the monthly allowance given to their children [35]. Results from the present research shows that respondents that received more than thirty thousand naira monthly were more food secure.

Furthermore, it has been posited that maternal occupation has a major effect on the food security of household. This is supported by the findings of this research which records higher food security level among respondents whose mother are senior civil servants. This positive effect has been attributed to the findings that women typically spend more of their income on food and health of the household which is also evident in the results of this research; the respondents that live off campus with their parents/guardian were more food secure than others that live in the campus or off campus without their parents/guardian. Furthermore, it has been posited that in Africa, women's income has greater effect on household food security than men's income [36]. Level of mother's education has also been reported to affect food security. This has been posited that one of the measures to ensure food security of households was the level of education, especially mother's education level. This is because higher level of education entails better understanding of child health and better diet which are important factors for food security [37]. This is similar to the findings of the present study; respondents whose mothers have a higher educational qualifications were more food secure. Another socio-economic characteristic posited to play a role in food security is household size. Records have shown that increase in household size is directly proportional to increase in food insecurity [38]. It was recorded in this research that household size of 5 7 is more food insecure with severe hunger than household size of 1-2 and 3-4.

The cost of living of the respondents also analyzed to document how much is spent on feeding, transport and assignments/academic activities. Findings indicate that the respondents with higher monthly allowance spend more on feeding than the others and thus are more food secure, this is in agreement with [38] who reported that increase in poverty increases food insecurity. It has been posited that students from lowincome families have difficulty covering the costs of attending college which can further inhibit completion of their studies in the university [39].

Needy students often have to work long hours [40], forgo the purchase of books and other necessary academic requirements [41]. Hence, compensatory feeding pattern/coping strategy of respondents was also documented. Findings indicate that most of the respondents take up any kind of work to raise funds in school. Other compensatory feeding pattern engaged in to abate food insecurity was mainly borrowing money from friends/neighbors/relatives which is in agreement with the report of [12] 
Unavailability of insufficient funds to meet basic needs leads to feelings of frustration among respondents as recorded in this study and this has been reported to be common among students especially medical students; some of the stressors are academic and social related [42]; others include financial constrains and worries about the future [43]. Everyone wants to live a life of good quality and this is believed by many as a sign of successful development [44]. Sadly though this is not so among university students as records have shown. Besides feelings of frustration brought about by unavailability of sufficient funds, findings show that academic and social areas of their life also cause these negative feelings as earlier posited by [42]. Further investigations also showed that the area of their life that suffer most due to these unhealthy feeling of frustration is academics which is in agreement with earlier findings by [41] and this plays a role in the feeling of unsatisfied quality of life recorded among the respondents even though most of them see academic achievement as the most important determinant of achieving their future prospects. No wonder they go the extra mile to ensure they are graduates.

\section{CONCLUSION}

High level of food insecurity among university students and this is more among students that live off campus without their parents/guardian. Other socio-economic factors such as level of mother's education, maternal occupation and household income are directly proportional to food security of students; however household size is indirectly proportional as increase in size of the household led to decrease in food security. In an effort to combat this, students take up any kind of work, borrow money or collect food from friends/neighbors/relatives. One major effect of this food insecurity is feelings of frustration and dissatisfaction with quality of life among the students even though they view academic achievement as a major determinant of achieving future prospects.Parents/guardian should ensure that their children/ward have enough monthly allowance to feed well and where possible, disallow them from living away from home. Furthermore, universities should create conducive atmosphere for learning by ensuring that the syllabus, time table and expectations from the students are not stressful.

\section{REFERENCES}

[1] Bickel, G., Nord, M., Price, C., Hamilton, W and Cook, J, "Measuring food security in the United States: guide to measuring household food security", Revised 2000, Alexandria, Va, US Dept of Agriculture. 2000.

[2] Idachaba, F.S, "Strategic and policies for food security and economic development in Nigeria", Central Bank of Nigeria, Lagos. 2006.

[3] Andersen, P. P, "Food security: definition and measurement", Food security, 1 (1): 5-7.2009.

[4] Wolfe,W.S and Frongillo, E.A, "Building household food-security measurement tools from the ground up", Food and nutrition bulletin, 22(1):5-12. 2001 .

[5] Pheley, A.M., Holben, D.H., Graham, A.S. and Simpson, C, "Food security and perceptions of health status: a preliminary study in rural Appalachia", Journal of Rural Health, 18:447-454. 2002.

[6] Kennedy, E. and Peters, P, "Household food security and child nutrition: the interaction of income and gender of household head", World development, 20(8):1077-1085. 1992.

[7] Rose, D, "Economic determinants and dietary consequences of food insecurity in the United States", Journal of Nutrition, 129:51720. 1999.

[8] González, W., Jiménez, A., Madrigal, G., Muñoz, L.M. and Frongillo, E.A, "Development and validation of measure of household food insecurity in urban costa rica confirms proposed generic questionnaire", Journal of Nutrition, 138(3):587-592. 2008.

[9] Matheson, D.M., Varady, J., Varady, A. and Killen, J.D, "Household food security and nutritional status of Hispanic children in the fifth grade" Journal of Clinical Nutrition, 76(1):210-217. 2002.

[10] Ali, D., Saha, K.K., Nguyen, P.H., Diressie, M.T., Ruel, M.T., Menon, P. and Rawat, R, "Household food insecurity is associated with higher child undernutrition in bangladesh, ethiopia, and vietnam, but the effect is not mediated by child dietary diversity", Journal of Nutrition, 143 (12): 2015-2021. 2013.

[11] Bernal, J., Frongillo, E.A., Herrera, H. and Rivera, J, "Children live, feel, and respond to experiences of food insecurity that compromise their development and weight status in Peri-Urban Venezuela”, Journal of Nutrition. 142 (7): 1343-1349. 2012.

[12] Feinberg, E., Kavanagh, P.L., Young, R.L and Prudent, N, "Food insecurity and compensatory feeding practices among urban black families", Pediatrics, 122:e854. 2008

[13] FAO, "The State of food insecurity in the world. Food and agriculture organization of the United Nations. Viale delle Terme di Caracalla, 00153 Rome, Italy. 2006.

[14] Clover, J, "Food Security in Sub-saharan Africa", African Security Review, 12, 1. 2003.

[15] Fakayode, S.B., Rahji, M.A.Y., Oni, O.A. and Adeyemi, M.O, "An assessment of food security situations of farm households in Nigeria: a USDA approach”, The social sciences ,4(1): 24-29. 2009.

[16] Ojo, O.E. and Adebayo, P.F, "Food security in nigeria: an overview”, European Journal of Sustainable Development, 1(2): 199-222. 2012.

[17] Oyebanjo, O., Ambali, O.I. and Akerele, E.O, "Determinants of food security status and incidence of food insecurity among rural farming households in ijebu division of Ogun State Nigeria", Journal of Agricultural Science and Environment; 13; 92-103. 2013.

[18] Orefi, A, "Food security in Nigeria and South Africa: policies and challenges", Journal of Human Ecology, 38(1): 31-35. 2012.

[19] Amaza, P., Abdoulaye, T., Kwaghe, P., Tegbaru, A, "Changes in household food security and poverty status in PROSAB area of Southern Borno State, Nigeria", International Institute of Tropical Agriculture (IITA) Promoting Sustainable Agriculture in Borno State (PROSAB). 2009. 49 pp. Available: www.iita.org. accessed 25th June, 2015.

[20] Adepoju, A.O. and Adejare, K.E, "Food insecurity status of rural households during the post-planting season in Nigeria. Journal of Agriculture and Sustainablilty, 4 (1):16-35. 2013. 
[21] Ajani, S.R., Badejo, C.A. and Yusuf, B.O, "Measuring household food insecurity in selected Local Government Areas of Lagos and Ibadan, Nigeria", Pakistan Journal of Nutrition, 5 (1): 62-67. 2006.

[22] Omotesho, O.A. and Muhammad-Lawal, A, "Optimal food plan for rural households' food security in Kwara State, Nigeria: the goal programming approach", Journal of Agricultural Biotechnology and Sustainable Development. 2(1):7-14. 2010.

[23] Odusina, O.A, "Assessment of households' food access and food insecurity in urban Nigeria: a case study of Lagos metropolis", Global Journal of Human-Social Science: Economics, 14(1): 20-30. 2014.

[24] Omonona, B.T., Agoi, G.A, "An analysis of food security situation among Nigerian urban households: evidence from Lagos state, Nigeria, Journal of Central European Agriculture, 8(3):397-406. 2007.

[25] Adebayo, O.O, "Family income among small scale farmers a panacea for household food security in Oyo State, Nigeria", Research on Humanities and Social Sciences, (7):32. 2012.

[26] Idrisa, Y.L., Gwary. M.M. and Shehu H, "Analysis of food security status among farming households in Jere Local Government of Borno State, Nigeria", Journal of Tropical Agriculture, Food, Environment and Extension, 7(3): 199 -205. 2008.

[27] Hamelin, A.M., Habicht, J.P. and Beaudry, M, "Food insecurity: consequences for the household and broader social implications" Journal of Nutrition, 129(2): 525S-528S. 1999.

[28] Jyoti, D.F., Frongillo, E.A. and Jones, S.J, "Food insecurity affects school children's academic performance, weight gain, and social skills", Journal of Nutrition, 135(12): 2831-2839. 2005.

[29] Stuff, J.E., Casey, P.H., Szeto, K.L., Gossett, J.M., Robbins, J.M., Simpson, P.M. et al., "Household food insecurity is associated with adult health status", Journal of Nutrition, 134(9): 2330-2335. 2004.

[30] Vanguard News, "Imo judiciary shut down over non-payment of salaries", 2016. Available at: http://www.vanguardngr.com/2016/05/imo-judiciary-shut-down-over-non-payment-of-salaries/. Accessed 7 July 2016.

[31] Nigerian eye, "Gov Ajimobi Threatens Workers With Non-Payment of Salaries", 2016. Availableat:http://www.nigerianeye.com/2016/06/gov-ajimobi-threatens-workers-with-non.html. Accessed 7 July 2016

[32] Today, "Salary", 2016. Available at: https://www.today.ng/tag/salary. Accessed 7 June 2016.

[33] Baum, S., Kurose, C. and McPherson, M, "An overview of American higher education", Future of Children, 23(1), 17-39. 2013.

[34] Belfield, C.R. and Bailey, T, "The benefits of attending community college: a review of the evidence", Community College Review, 39(1), 46-68. 2011.

[35] Bailey, J. and Dynarski, M, "Gains and gaps: Changing inequality in US college entry and completion", Cambridge, Mass. 2011.

[36] Thomas, D. and Chen, C.L, "Income shares and shares of income. Empirical tests of models of household resource allocations, labor and population", Program working paper, Santa Monica, Calif., U.S.A.:Rand Corporation. No.94-08. 1994.

[37] Quandt, S.A., Arcury T.A., Early, J., Tapia, J. and Davis, J.D, "Household food security among migrant and seasonal Latino farm workers in North Carolina", Public Health Reports, 119: 568-576. 2004.

[38] Ozlem, E. and Necat, O.M, "Impact of household socio-economic factors on food security: case of Adana", Pakistan Journal of Nutrition, 13 (1): 1-6, 2014.

[39] Engle, J. and Tinto, V, "Moving beyond access: college success for low-income, first generation students. Pell Institute for the Study of Opportunity in Higher Education. 2008

[40] Bozick, R, "Making it through the first year of college: the role of students' economic resources, employment, and living arrangements", Sociology of Education, 80(3), 261-285. 2007.

[41] Terriquez, V. and Gurantz, O, "Financial challenges in emerging adulthood and students decisions to stop out of college", Emerging Adulthood, 2167696814550684. 2014.

[42] Samira, S.B., Ali, I., Farhan, A., Alaa, A., Sajida, A., Saeed, R., et al., "Sources of stress and coping strategies among undergraduate medical students enrolled in a problem-based learning curriculum", Journal of Biomedical Education, 2015, Article ID 575139, 8 pages. 2015

[43] Sami, A.A., Redhwan, A.A., Mustafa, A.A., Krishna, G.R, "Stress and coping strategies of students in a medical faculty in Malaysia", Malaysian Journal of Medical Science, 18(3): 57-64. 2011.

[44] Wrosch, C., Scheier, M.F, "Personality and quality of life: the importance of optimism and goal adjustment", Quality of Life Research, 12, 59-72. 2003

Table 1: Socio-Demographic Characteristics of Respondents

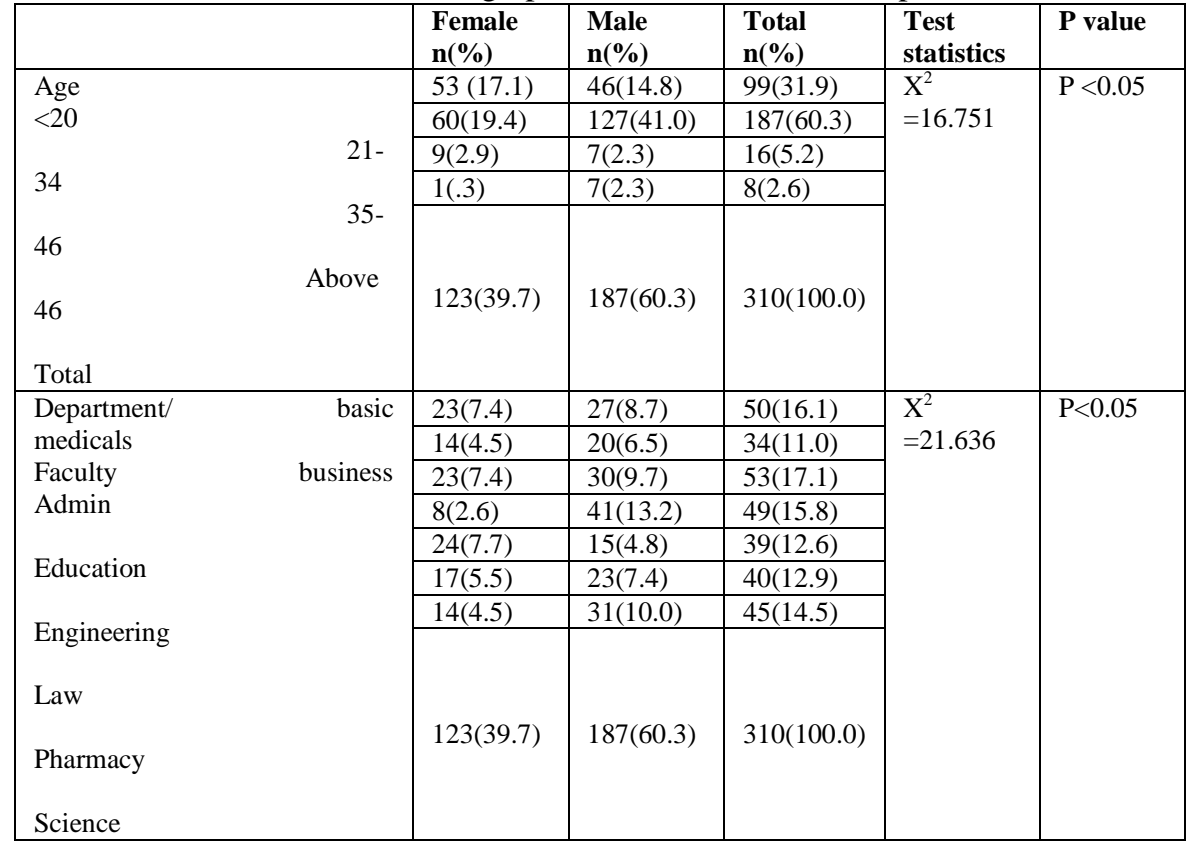




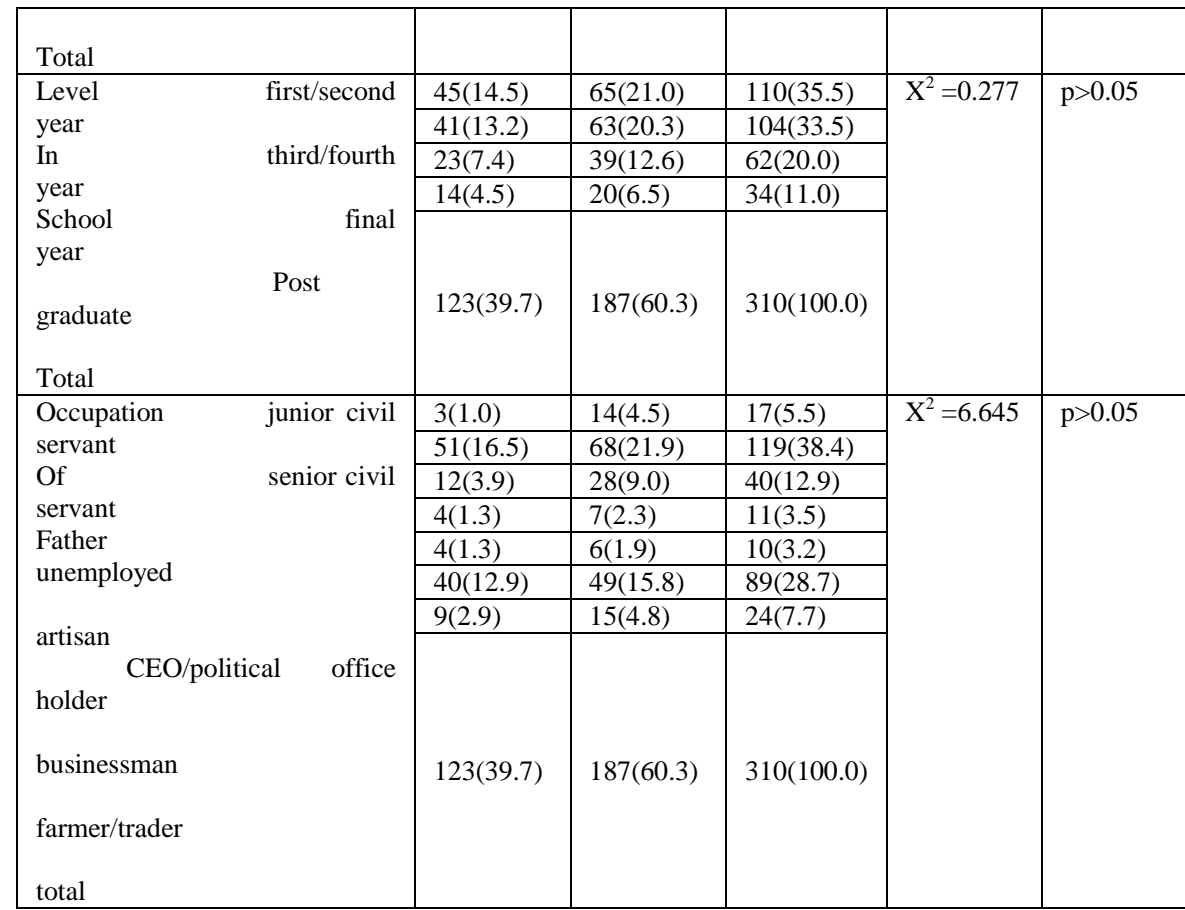

Table 2: Further Socio-Demographic Characteristics of Respondents

\begin{tabular}{|c|c|c|c|c|c|}
\hline & $\begin{array}{l}\text { Female } \\
\mathbf{n}(\%)\end{array}$ & $\begin{array}{l}\text { Male } \\
\text { n(\%) }\end{array}$ & Total n(\%) & $\begin{array}{l}\text { Test } \\
\text { statistics }\end{array}$ & P value \\
\hline \multirow{7}{*}{$\begin{array}{l}\text { Monthly } \\
\text { allowance }\end{array}$} & $27(8.7)$ & $37(11.9)$ & $64(20.6)$ & \multirow[t]{7}{*}{$X^{2}=2.656$} & \multirow[t]{7}{*}{$p>0.05$} \\
\hline & $47(15.2)$ & $60(19.4)$ & $107(34.5)$ & & \\
\hline & $15(4.8)$ & $33(10.6)$ & $48(15.5)$ & & \\
\hline & $10(3.2)$ & $18(5.8)$ & $28(9.0)$ & & \\
\hline & $7(2.3)$ & $11(3.5)$ & $18(5.8)$ & & \\
\hline & $17(5.5)$ & $28(9.0)$ & $45(14.5)$ & & \\
\hline & $123(39.7)$ & $187(60.3)$ & $310(100.0)$ & & \\
\hline \multirow{4}{*}{$\begin{array}{lr}\text { Is your } & \text { sometimes } \\
\text { Allowance always } & \text { often } \\
\text { Enough } & \text { most times } \\
\text { For you } & \text { total }\end{array}$} & $86(27.7)$ & $141(45.5)$ & $227(73.2)$ & \multirow[t]{4}{*}{$X^{2}=1.487$} & \multirow[t]{4}{*}{$p>0.05$} \\
\hline & $16(5.2)$ & $17(5.5)$ & $33(10.6)$ & & \\
\hline & $21(6.8)$ & $29(9.4)$ & $50(16.1)$ & & \\
\hline & $123(39.7)$ & $187(60.3)$ & $310(100.0)$ & & \\
\hline \multirow{4}{*}{$\begin{array}{c}\text { Residence } \\
\text { on campus } \\
\text { Off campus without } \mathrm{P} / \mathrm{G} \\
\text { Off campus with } \mathrm{P} / \mathrm{G} \\
\text { Total }\end{array}$} & $53(17.1)$ & $43(13.9)$ & $96(31.0)$ & \multirow[t]{4}{*}{$\mathrm{X}^{2}=25.843$} & \multirow[t]{4}{*}{$\mathrm{P}<0.05$} \\
\hline & $33(10.6)$ & $104(33.5)$ & $137(44.2)$ & & \\
\hline & $37(11.9)$ & 40(12.9) & $77(24.8)$ & & \\
\hline & $123(39.7)$ & $187(60.3)$ & $310(100.0)$ & & \\
\hline \multirow{9}{*}{$\begin{array}{lr}\text { Occupation } & \text { junior civil servant } \\
\text { Of } & \text { senior civil servant } \\
\text { Mother } & \text { unemployed } \\
& \text { Artisan } \\
& \text { CEO/political office holder } \\
\text { Businesswoman } \\
\text { Farmer/trader } \\
\text { total }\end{array}$} & $9(2.9)$ & $15(4.8)$ & $24(7.7)$ & \multirow[t]{9}{*}{$X^{2}=3.535$} & \multirow[t]{9}{*}{$\mathrm{p}>0.05$} \\
\hline & $28(9.0)$ & $54(17.4)$ & $82(26.5)$ & & \\
\hline & $7(2.3)$ & $12(3.9)$ & $19(6.1)$ & & \\
\hline & $3(1.0)$ & $3(1.0)$ & $6(1.9)$ & & \\
\hline & & & & & \\
\hline & $2(.6)$ & $2(.6)$ & $4(1.3)$ & & \\
\hline & $65(21.0)$ & $82(26.5)$ & $147(47.4)$ & & \\
\hline & $9(2.9)$ & $19(6.1)$ & $28(9.0)$ & & \\
\hline & $123(39.7)$ & $187(60.3)$ & $310(100.0)$ & & \\
\hline \multirow{6}{*}{\begin{tabular}{lc} 
level of & primary \\
Maternal & secondary \\
Education & tertiary \\
& No formal education \\
\multicolumn{2}{c}{ Vocational/trained education } \\
\multicolumn{2}{c}{ Total }
\end{tabular}} & $0(.0)$ & $6(1.9)$ & $6(1.9)$ & \multirow[t]{6}{*}{$X^{2}=6.004$} & \multirow[t]{6}{*}{$\mathrm{p}>0.05$} \\
\hline & $63(20.3)$ & $87(28.1)$ & $150(48.4)$ & & \\
\hline & $57(18.4)$ & $85(27.4)$ & $142(45.8)$ & & \\
\hline & $2(.6)$ & $8(2.6)$ & $10(3.2)$ & & \\
\hline & $1(.3)$ & $1(.3)$ & $2(.6)$ & & \\
\hline & $123(39.7)$ & $187(60.3)$ & $310(100.0)$ & & \\
\hline Household & 41(13.2) & $62(20.0)$ & $103(33.2)$ & \multirow[t]{4}{*}{$X^{2}=0.653$} & \multirow[t]{4}{*}{$p>0.05$} \\
\hline Size & 61(19.7) & $99(31.9)$ & $160(51.6)$ & & \\
\hline Above 7 & $21(6.8)$ & $26(8.4)$ & $47(15.2)$ & & \\
\hline Total & $123(39.7)$ & $187(60.3)$ & $310(100.0)$ & & \\
\hline
\end{tabular}

business admin- business administration p/g-parents/guardian. 
Table 3: Distribution of Respondents' Food Security According to Residence, Involvement in Economic Activity, Occupation of Mother, Monthly Allowance, Level in School, Gender and Department/Faculty

\begin{tabular}{|c|c|c|c|c|c|c|c|}
\hline & $\begin{array}{c}\text { Food } \\
\text { secure } \\
\mathrm{n}(\%)\end{array}$ & $\begin{array}{l}\text { Food } \\
\text { insecure } \\
\text { without } \\
\text { hunger } \\
\mathrm{n}(\%)\end{array}$ & $\begin{array}{l}\text { Food } \\
\text { insecure } \\
\text { with } \\
\text { moderate } \\
\text { hunger } \\
\mathrm{n}(\%)\end{array}$ & $\begin{array}{l}\text { Food } \\
\text { insecure } \\
\text { with } \\
\text { severe } \\
\text { hunger } \\
\mathrm{n}(\%)\end{array}$ & Total & $\begin{array}{l}\text { Test } \\
\text { statistics }\end{array}$ & $\begin{array}{l}\text { p- } \\
\text { value }\end{array}$ \\
\hline \multirow{4}{*}{$\begin{array}{r}\text { Residence on campus } \\
\text { Off campus without } \mathrm{P} / \mathrm{G} \\
\text { Off campus with } \mathrm{P} / \mathrm{G} \\
\text { total }\end{array}$} & $2(0.6)$ & $8(2.6)$ & $26(8.4)$ & $60(19.4)$ & $96(31.0)$ & \multirow{4}{*}{$\begin{array}{l}X^{2} \\
=13.386\end{array}$} & \multirow[t]{4}{*}{$\mathrm{P}<0.05$} \\
\hline & 13(4.2) & $16(5.2)$ & $26(8.4)$ & $82(26.5)$ & $137(44.2)$ & & \\
\hline & $1(0.3)$ & $13(4.2)$ & $18(5.8)$ & $45(14.5)$ & $77(24.8)$ & & \\
\hline & $16(5.2)$ & $37(11.9)$ & $70(22.6)$ & $187(60.3)$ & $310(100)$ & & \\
\hline \multirow{3}{*}{$\begin{array}{lr}\text { Do you engage in } & \text { yes } \\
\text { Any economic } & \text { no } \\
\text { Activity } & \text { total }\end{array}$} & $8(2.6)$ & $17(5.5)$ & $31(10.0)$ & $100(32.3)$ & $156(50.3)$ & \multirow{3}{*}{$\begin{array}{l}\mathrm{X}^{2} \\
=2.048\end{array}$} & \multirow[t]{3}{*}{$p>0.05$} \\
\hline & $8(2.6)$ & $20(6.5)$ & $39(12.6)$ & $87(28.1)$ & $154(49.7)$ & & \\
\hline & $16(5.2)$ & $37(11.9)$ & $70(22.6)$ & $187(60.3)$ & $310(100)$ & & \\
\hline \multirow{8}{*}{$\begin{array}{lr}\text { Occupation } & \text { junior C.S } \\
\text { Of } & \text { senior C.S } \\
\text { Mother } & \text { unemployed } \\
& \text { Artisan } \\
\text { CEO/political O.H } \\
\text { Businesswoman } \\
\text { Farmer/trader } \\
\text { Total }\end{array}$} & $1(0.3)$ & $0(0.0)$ & $7(2.3)$ & $16(5.2)$ & $24(7.7)$ & \multirow{8}{*}{$\begin{array}{l}\mathrm{X}^{2} \\
=33.414\end{array}$} & \multirow[t]{8}{*}{$\mathrm{P}<0.05$} \\
\hline & $7(2.3)$ & $6(1.9)$ & $17(5.5)$ & $52(16.8)$ & $82(26.5)$ & & \\
\hline & $1(0.3)$ & $1(0.3)$ & $6(1.9)$ & $11(3.5)$ & 19(6.1) & & \\
\hline & $0(0)$ & $1(0.3)$ & $2(0.6)$ & $3(1.0)$ & $6(1.9)$ & & \\
\hline & $2(0.6)$ & $0(0)$ & $1(0.3)$ & $1(0.3)$ & $4(1.3)$ & & \\
\hline & $4(1.3)$ & $24(7.7)$ & $34(11.0)$ & $85(27.4)$ & $147(47.4)$ & & \\
\hline & $1(0.3)$ & $5(1.6)$ & $3(1.0)$ & $19(6.1)$ & $28(9.0)$ & & \\
\hline & $16(5.2)$ & $37(11.9)$ & $70(22.6)$ & $187(60.3)$ & $310(100)$ & & \\
\hline \multirow{7}{*}{$\begin{array}{rc}\text { Monthly } & <\mathrm{N} 5,000 \\
\text { Allow. N5,000-N10,000 } & \text { N11,000-N16,000 } \\
\mathrm{N} 17,000-\mathrm{N} 24,000 \\
\mathrm{~N} 25,000-\mathrm{N} 30,000 \\
\text { Above N30,000 } \\
\text { Total }\end{array}$} & $1(0.3)$ & $4(1.3)$ & $10(3.2)$ & $49(15.8)$ & $64(20.6)$ & \multirow{7}{*}{$\begin{array}{l}X^{2} \\
=31.048\end{array}$} & \multirow[t]{7}{*}{$\mathrm{P}<0.05$} \\
\hline & $4(1.3)$ & $15(4.8)$ & $23(7.4)$ & $65(21.0)$ & $107(34.5)$ & & \\
\hline & $0(0.0)$ & $9(2.9)$ & $13(4.2)$ & $26(8.4)$ & $48(15.5)$ & & \\
\hline & $2(0.6)$ & $3(1.0)$ & $9(2.9)$ & $14(4.5)$ & $28(9.0)$ & & \\
\hline & $1(0.3)$ & $1(0.3)$ & $5(1.6)$ & 11(3.5) & $18(5.8)$ & & \\
\hline & $8(2.6)$ & $5(1.6)$ & $10(3.2)$ & $22(7.1)$ & $45(14.5)$ & & \\
\hline & $16(5.2)$ & $37(11.9)$ & $70(22.6)$ & $187(60.3)$ & $310(100)$ & & \\
\hline \multirow{5}{*}{$\begin{array}{lr}\text { Level } & \text { first/second year } \\
\text { In } & \text { third/fourth year } \\
\text { School } & \text { Final year } \\
& \text { Post graduate } \\
& \text { Total } \\
\end{array}$} & $1(0.3)$ & $12(3.9)$ & $34(11.0)$ & $63(20.3)$ & $110(35.5)$ & \multirow{5}{*}{$\begin{array}{l}\mathrm{X}^{2} \\
=34.889\end{array}$} & \multirow[t]{5}{*}{$\mathrm{P}<0.05$} \\
\hline & $6(1.9)$ & $14(4.5)$ & $18(5.8)$ & $66(21.3)$ & $104(33.5)$ & & \\
\hline & $1(0.3)$ & $8(2.6)$ & $12(3.9)$ & $41(13.2)$ & $62(20.0)$ & & \\
\hline & $8(2.6)$ & $3(1.0)$ & $6(1.9)$ & $17(5.5)$ & $34(11.0)$ & & \\
\hline & $16(5.2)$ & $37(11.9)$ & $70(22.6)$ & $187(60.3)$ & $310(100)$ & & \\
\hline \multirow{3}{*}{$\begin{array}{cc}\text { Gender } & \text { female } \\
\text { Male } \\
\text { Total }\end{array}$} & $7(2.3)$ & $18(5.8)$ & $30(9.7)$ & $68(21.9)$ & $123(39.7)$ & \multirow{3}{*}{$\begin{array}{l}\mathrm{X}^{2} \\
=2.509\end{array}$} & \multirow[t]{3}{*}{$\mathrm{P}>0.05$} \\
\hline & $9(2.9)$ & $19(6.1)$ & $40(12.9)$ & $119(38.4)$ & $187(60.3)$ & & \\
\hline & $16(5.2)$ & $37(11.9)$ & $70(22.6)$ & $187(60.3)$ & $310(100)$ & & \\
\hline \multirow{8}{*}{$\begin{array}{lr}\text { Depart- } & \text { basic medicals } \\
\text { Ment/ business Admin } \\
\text { Faculty } & \text { Education } \\
& \text { Engineering } \\
\text { Law } \\
\text { Pharmacy } \\
\text { Science } \\
\text { total }\end{array}$} & $6(1.9)$ & $7(2.3)$ & 11(3.5) & $26(8.4)$ & $50(16.1)$ & \multirow{8}{*}{$\begin{array}{l}X^{2} \\
=16.793\end{array}$} & \multirow[t]{8}{*}{$\mathrm{p}>0.05$} \\
\hline & $1(0.3)$ & $3(1.0)$ & $9(2.9)$ & $21(6.8)$ & $34(11.0)$ & & \\
\hline & $3(1.0)$ & $5(1.6)$ & $10(3.2)$ & $35(11.3)$ & $53(17.1)$ & & \\
\hline & $1(0.3)$ & $3(1.0)$ & $9(2.9)$ & $36(11.6)$ & $49(15.8)$ & & \\
\hline & $1(0.3)$ & $5(1.6)$ & $9(2.9)$ & $24(7.7)$ & $39(12.6)$ & & \\
\hline & $3(1.0)$ & $7(2.3)$ & $8(2.6)$ & $22(7.1)$ & $40(12.9)$ & & \\
\hline & $1(0.3)$ & $7(2.3)$ & $14(4.5)$ & $23(7.4)$ & $45(14.5)$ & & \\
\hline & $16(5.2)$ & $37(11.9)$ & $70(22.6)$ & $187(60.3)$ & $310(100)$ & & \\
\hline
\end{tabular}

Allow- allowance, p/g-parents/guardian, c.s- civil servant, o.h- office holder

Table 4: Further Distribution of Respondents' Food Security According to Level of Maternal Education, Occupation of Father and Household Size

\begin{tabular}{|c|c|c|c|c|c|c|c|}
\hline & $\begin{array}{l}\text { Food } \\
\text { secure } \\
\mathrm{n}(\%)\end{array}$ & $\begin{array}{c}\text { Food } \\
\text { insecure } \\
\text { without } \\
\text { hunger } \\
\mathrm{n}(\%)\end{array}$ & $\begin{array}{c}\text { Food } \\
\text { insecure } \\
\text { with } \\
\text { moderate } \\
\text { hunger } \\
\mathrm{n}(\%)\end{array}$ & $\begin{array}{c}\text { Food } \\
\text { insecure } \\
\text { with } \\
\text { severe } \\
\text { hunger } \\
\mathrm{n}(\%)\end{array}$ & Total & $\begin{array}{l}\text { Test } \\
\text { statistics }\end{array}$ & p-value \\
\hline \multirow{6}{*}{$\begin{array}{l}\text { Level of } \\
\text { primary } \\
\text { Maternal } \\
\text { secondary } \\
\text { Education } \\
\text { tertiary } \\
\quad \text { No formal } \\
\text { education } \\
\text { Vocational/trained } \\
\text { ed. }\end{array}$} & $0(0.0)$ & $1(0.3)$ & $2(0.6)$ & $3(1.0)$ & $6(1.9)$ & \multirow[t]{7}{*}{$\mathrm{X}^{2}=5.970$} & \multirow[t]{7}{*}{$\mathrm{p}>0.05$} \\
\hline & $5(1.6)$ & $20(6.5)$ & $33(10.6)$ & $92(29.7)$ & $150(48.4)$ & & \\
\hline & $11(3.5)$ & $15(4.8)$ & $32(10.3)$ & $84(27.1)$ & $142(45.8)$ & & \\
\hline & $0(0.0)$ & $1(0.3)$ & $2(0.6)$ & $7(2.3)$ & $10(3.2)$ & & \\
\hline & $0(0.0)$ & $0(0.0)$ & $1(0.3)$ & $1(0.3)$ & $2(0.6)$ & & \\
\hline & $16(5.2)$ & $37(11.7)$ & $70(22.6)$ & $187(60.3)$ & $310(100)$ & & \\
\hline Total & & & & & & & \\
\hline Occupation junior & $0(0.0)$ & $2(0.6)$ & $5(1.6)$ & $10(3.2)$ & $17(5.5)$ & $X^{2}$ & $\mathrm{P}<0.005$ \\
\hline
\end{tabular}


Food Security and Outlook on Life of Undergraduates

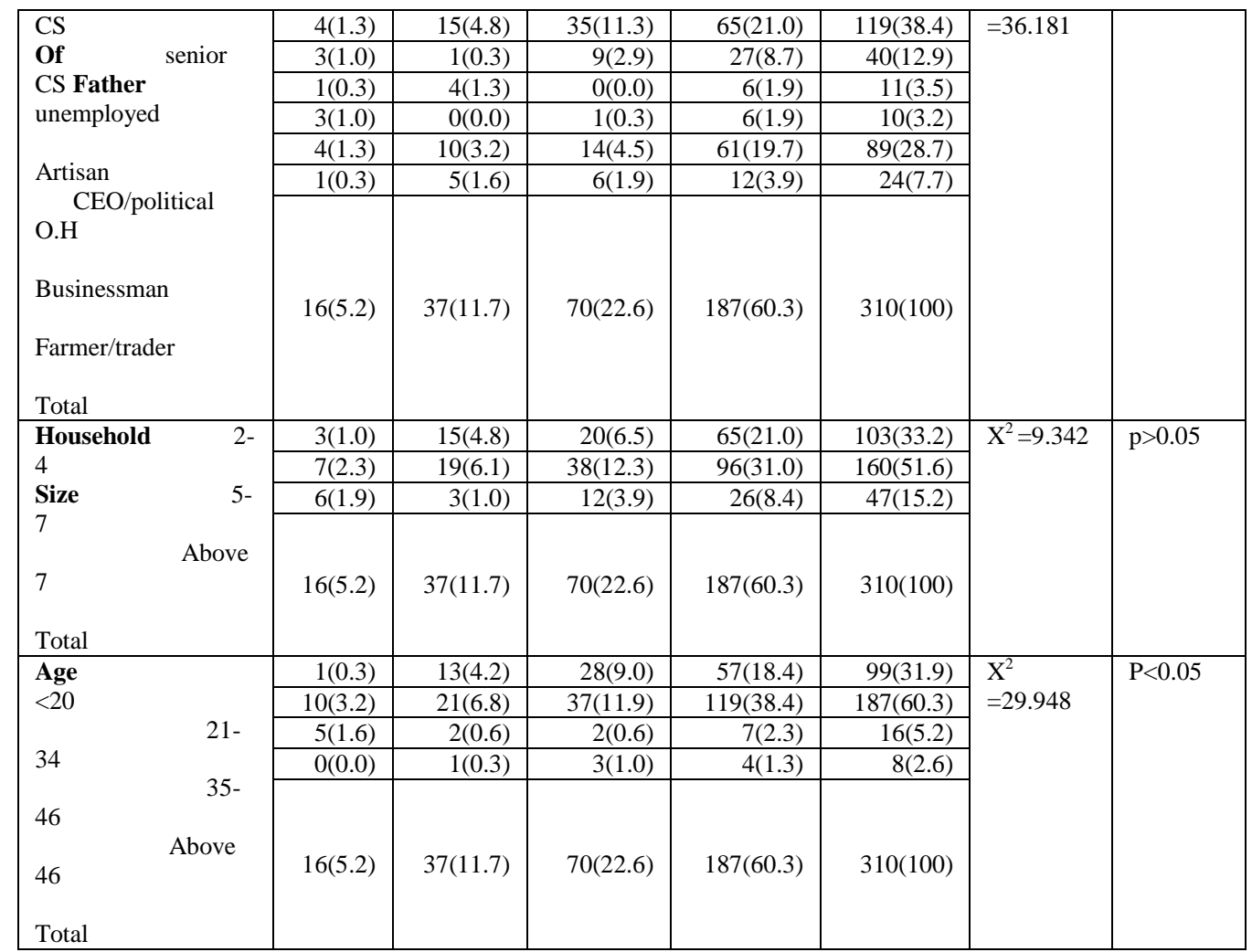

P/G-Parents/guardian, CS-Civil servant, O.H-Office holder, Ed-education, Admin-administration

Table 5: Distribution of Respondents' Cost of Living According to Gender and Monthly Allowance

\begin{tabular}{|c|c|c|c|c|}
\hline \multirow[t]{2}{*}{ Monthly expense in Naira } & \multicolumn{2}{|l|}{ Gender } & \multirow{2}{*}{$\begin{array}{l}\text { Total } \\
\mathrm{n}(\%)\end{array}$} & \multirow{2}{*}{$\begin{array}{l}\text { Test statistics/ } \\
\text { p- value }\end{array}$} \\
\hline & Female $\mathrm{n}(\%)$ & Male $\mathrm{n}(\%)$ & & \\
\hline \multirow{4}{*}{ Above N5000 } & $\begin{array}{l}5 \\
(8.1)\end{array}$ & $\begin{array}{l}34 \\
(11)\end{array}$ & $59(19)$ & \multirow[t]{4}{*}{$0.224 / 0.894$} \\
\hline & $\begin{array}{l}33 \\
(11)\end{array}$ & $\begin{array}{l}51 \\
(16)\end{array}$ & $84(27)$ & \\
\hline & $\begin{array}{l}65 \\
(21)\end{array}$ & $\begin{array}{l}102 \\
(34)\end{array}$ & $\begin{array}{l}167 \\
(54)\end{array}$ & \\
\hline & $\begin{array}{l}123 \\
(40)\end{array}$ & $\begin{array}{l}187 \\
(60)\end{array}$ & $\begin{array}{l}310 \\
(100)\end{array}$ & \\
\hline \multirow{4}{*}{ Above N5000 } & $\begin{array}{l}40 \\
(13)\end{array}$ & $\begin{array}{l}76 \\
(24)\end{array}$ & $116(37)$ & \multirow[t]{4}{*}{$7.126 / 0.028$} \\
\hline & $\begin{array}{l}50 \\
(16)\end{array}$ & $\begin{array}{l}49 \\
(16)\end{array}$ & $99(32)$ & \\
\hline & $\begin{array}{l}33 \\
(11)\end{array}$ & $\begin{array}{l}62 \\
(20)\end{array}$ & $95(31)$ & \\
\hline & $\begin{array}{l}123 \\
(40)\end{array}$ & $\begin{array}{l}187 \\
(60)\end{array}$ & $\begin{array}{l}310 \\
(100)\end{array}$ & \\
\hline \multirow{5}{*}{ 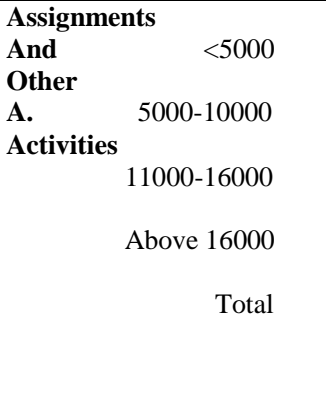 } & $35(11.3)$ & 74(23.9) & $109(35.2)$ & \multirow[t]{5}{*}{$4.389 / 0.222$} \\
\hline & $\begin{array}{l}62 \\
(20)\end{array}$ & $79(25.5)$ & $\begin{array}{l}141 \\
(45.5)\end{array}$ & \\
\hline & $\begin{array}{l}15 \\
(4.8)\end{array}$ & $\begin{array}{l}17 \\
(5.5)\end{array}$ & $\begin{array}{l}32 \\
(10.3)\end{array}$ & \\
\hline & $11(3.5)$ & $\begin{array}{l}17 \\
(5.5)\end{array}$ & $\begin{array}{l}28 \\
(9.0)\end{array}$ & \\
\hline & $\begin{array}{l}123 \\
(39.7)\end{array}$ & $187(60.3)$ & $310(100)$ & \\
\hline
\end{tabular}

A-Academic 
Table 6: Distribution of Respondents' Food Security According to Coping Strategy Engaged in when Food/Money is not enough

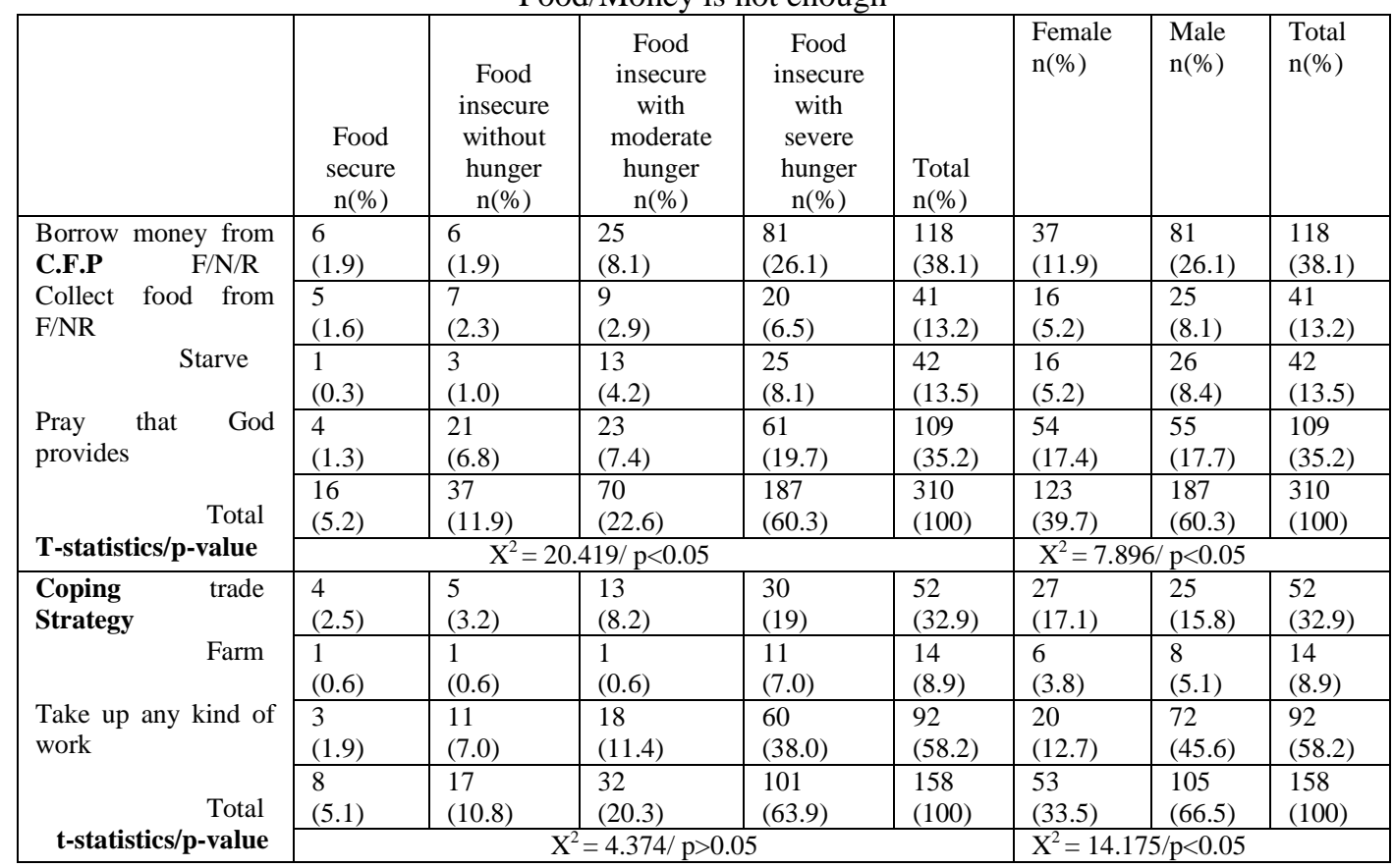

C.F.P- compensatory feeding pattern, F/N/R-friends/neighbors/relatives

Table 7: Distribution of Respondents' Quality of Life According to Gender

\begin{tabular}{|c|c|c|c|c|}
\hline & \multicolumn{2}{|c|}{ Gender } & \multirow{2}{*}{$\begin{array}{l}\text { Total } \\
\mathrm{n}(\%)\end{array}$} \\
\hline & & $\begin{array}{l}\text { Female } \\
\mathrm{n}(\%)\end{array}$ & $\begin{array}{l}\text { Male } \\
\mathrm{n}(\%)\end{array}$ & \\
\hline \multirow{5}{*}{$\begin{array}{l}\text { Do you feel frustrated that } \\
\text { you don't have enough } \\
\text { money to meet your } \\
\text { basic needs }\end{array}$} & \multirow{5}{*}{$\begin{array}{r}\text { often true } \\
\text { sometimes true } \\
\text { never true } \\
\text { total } \\
\text { atistics/p-value }\end{array}$} & $50(16.1)$ & $83(26.8)$ & $133(42.9)$ \\
\hline & & $50(16.1)$ & $72(23.2)$ & $122(39.4)$ \\
\hline & & $23(7.4)$ & $32(10.3)$ & $55(17.7)$ \\
\hline & & $123(39.7)$ & $187(60.3)$ & $310(100)$ \\
\hline & & \multicolumn{3}{|c|}{$\mathrm{X}^{2}=0.433 / \mathrm{p}>0.05$} \\
\hline \multirow{6}{*}{$\begin{array}{l}\text { List three things } \\
\text { you find } \\
\text { frustrating as } \\
\text { a student }\end{array}$} & \multirow{6}{*}{$\begin{array}{c}\text { health related } \\
\text { academic related } \\
\text { economic related } \\
\text { social related } \\
\text { total } \\
\text { tatistics/p-value }\end{array}$} & $6(1.9)$ & $7(2.3)$ & $13(4.2)$ \\
\hline & & $53(17.1)$ & $55(17.7)$ & $108(34.8)$ \\
\hline & & $50(16.1)$ & $102(32.9)$ & $152(49.0)$ \\
\hline & & $14(4.5)$ & $23(7.4)$ & $37(11.9)$ \\
\hline & & $123(39.7)$ & $187(60.3)$ & $310(100)$ \\
\hline & & \multicolumn{3}{|c|}{$\mathrm{X}^{2}=7.186 / \mathrm{p}>0.05$} \\
\hline \multirow{7}{*}{$\begin{array}{l}\text { What area of your } \\
\text { life suffers } \\
\text { as a result of } \\
\text { not having enough } \\
\text { allowance }\end{array}$} & \multirow{7}{*}{$\begin{array}{r}\text { healthcare } \\
\text { entertainment } \\
\text { tional wellbeing } \\
\text { feeding } \\
\text { academics } \\
\text { total } \\
\text { tistics/p-value }\end{array}$} & $9(2.9)$ & $25(8.1)$ & $34(11.0)$ \\
\hline & & $23(7.4)$ & $34(11.0)$ & $57(18.4)$ \\
\hline & & $24(7.8)$ & $31(10.0)$ & $55(17.8)$ \\
\hline & & $28(9.1)$ & $43(13.9)$ & $71(23.0)$ \\
\hline & & $38(12.3)$ & $54(17.5)$ & $92(29.8)$ \\
\hline & & $122(39.5)$ & $187(60.5)$ & $309(100)$ \\
\hline & & \multicolumn{3}{|c|}{$\mathrm{X}^{2}=2.952 / \mathrm{p}>0.05$} \\
\hline \multirow{5}{*}{$\begin{array}{l}\text { Do you feel unsure } \\
\text { of your future } \\
\text { prospects }\end{array}$} & \multirow{5}{*}{$\begin{array}{r}\text { often true } \\
\text { sometimes true } \\
\text { never true } \\
\text { total } \\
\text { tatistics/p-value }\end{array}$} & $16(5.2)$ & $16(5.2)$ & $32(10.3)$ \\
\hline & & $28(9.0)$ & $55(17.7)$ & $83(26.8)$ \\
\hline & & $79(25.5)$ & $116(37.4)$ & $195(62.9)$ \\
\hline & & $123(39.7)$ & $187(60.3)$ & $310(100)$ \\
\hline & & $\mathrm{X}^{2}=2.70$ & 0.05 & \\
\hline \multirow{5}{*}{$\begin{array}{l}\text { Do you feel } \\
\text { satisfied with } \\
\text { your quality of life }\end{array}$} & \multirow{5}{*}{$\begin{array}{r}\text { often true } \\
\text { sometimes true } \\
\text { never true } \\
\text { total } \\
\text { tatistics/p-value }\end{array}$} & $29(9.4)$ & $46(14.8)$ & $75(24.2)$ \\
\hline & & $70(22.6)$ & $93(30.0)$ & $163(52.6)$ \\
\hline & & $24(7.7)$ & $48(15.5)$ & $72(23.2)$ \\
\hline & & $123(39.7)$ & $187(60.3)$ & $310(100)$ \\
\hline & & $\mathrm{X}^{2}=1.97$ & 0.05 & \\
\hline \multirow{6}{*}{$\begin{array}{l}\text { What do you think } \\
\text { is the most important } \\
\text { determinant of achieving } \\
\text { your future prospects }\end{array}$} & \multirow{6}{*}{$\begin{array}{r}\text { academic achievement } \\
\text { family background } \\
\text { social affiliations } \\
\text { divine intervention } \\
\text { total } \\
\text { test statistics/p-value }\end{array}$} & $63(20.3)$ & $89(28.7)$ & $152(49.0)$ \\
\hline & & $8(2.6)$ & $5(1.6)$ & $13(4.2)$ \\
\hline & & $10(3.2)$ & $16(5.2)$ & $26(8.4)$ \\
\hline & & $42(13.5)$ & $77(24.8)$ & $119(38.4)$ \\
\hline & & $123(39.7)$ & $187(60.3)$ & $310(100)$ \\
\hline & & \multicolumn{2}{|c|}{$\mathrm{X}^{2}=3.766 / \mathrm{p}>0.05$} & \\
\hline
\end{tabular}

